\title{
Transatlantica
}

Revue d'études américaines. American Studies Journal

\section{Seeking Sam Selvon: Michel Fabre and the Fiction of the Caribbean}

\section{Kathie Birat}

\section{Q OpenEdition}

1 Journals

\section{Édition électronique}

URL : https://journals.openedition.org/transatlantica/4259

DOI : $10.4000 /$ transatlantica.4259

ISSN : $1765-2766$

Éditeur

Association française d'Etudes Américaines (AFEA)

\section{Référence électronique}

Kathie Birat, « Seeking Sam Selvon: Michel Fabre and the Fiction of the Caribbean », Transatlantica [En ligne], 1 | 2009, mis en ligne le 23 juin 2009, consulté le 15 septembre 2021. URL : http:// journals.openedition.org/transatlantica/4259; DOI : https://doi.org/10.4000/transatlantica.4259

Ce document a été généré automatiquement le 15 septembre 2021.

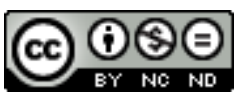

Transatlantica - Revue d'études américaines est mise à disposition selon les termes de la licence Creative Commons Attribution - Pas d'Utilisation Commerciale - Pas de Modification 4.0 International. 


\title{
Seeking Sam Selvon: Michel Fabre and the Fiction of the Caribbean
}

\author{
Kathie Birat
}

1 In his introduction to the special issue of Commonwealth dedicated to Michel Fabre, Jean-Pierre Durix refers to Fabre's curiosity and his desire to explore literatures outside of his explicit area of specialisation. ${ }^{1}$ Michel Fabre gave considerable attention to Caribbean literature and helped to define the place of authors like the Guyanese novelist Wilson Harris and the Saint Lucian poet Derek Walcott. Among the Caribbean writers who attracted his attention was Sam Selvon, a Trinidadian novelist whose exploration of themes related to Caribbean identity and particularly to language and the use of the vernacular helped to shape the fiction which was emerging from the area in the fifties and sixties. ${ }^{2}$ Fabre conducted interviews with the author in the 1970s and published several articles in which he examined in particular Selvon's use of dialect in his novels. The interviews and an article on the novels were published in Susheila Nasta's Critical Perspectives on Sam Selvon and a chapter on Selvon appeared in Bruce King's West Indian Literature ${ }^{3}$.

2 In the chapter he wrote for King's collection of criticism, Michel Fabre presented most of Selvon's published works, attempting to situate him in the context of a rapidly developing body of fiction produced by authors from the region. He pointed out the ways in which Selvon contributed to the creation of fiction aimed at a reading public both inside and outside the Caribbean. He attempted in particular to show how Selvon sought a balance between the use of cultural and social factors indigenous to Trinidad while at the same time calling upon aspects of a European and American literary tradition with which he was inevitably familiar. One of the factors to which he draws attention is Selvon's search for a narrative form and an idiom capable of giving a faithful representation of the world of his characters without succumbing to the pitfalls of didactic realism or ideology. This was, and continues to be, one of the major obstacles facing writers who wish to be read on their own terms rather than being catalogued as spokesmen for regional, ethnic or racial concerns. He says:

Selvon faced the problem of conveying this message to a double audience. Writing

for the wider European public as well as for his fellow-Trinidadians, he had to 
create a literary language suited to cultural particulars while creating a bond of sympathetic immediacy with foreign readers unconversant with West Indian culture who sometimes required nearly anthropological information. (Fabre 1995, 153)

3 Fabre clearly perceives the intimate relation between language, story and narrative form and understands that Selvon was attempting to establish a connection between the world he wished to represent and the narrative devices available to him both in the immediate context of Trinidad and the more distant one of Euorpean and American literature. He suggests that the opening paragraphs in Selvon's first novel, A Brighter Sun, which seek to place the story in the larger context of world events, can be compared to Dos Passos's use of the newsreel technique. He also sees that the situation of the extradiegetic narrator, who uses standard English, poses "a problem of tongue and tone". The narrator remains "somewhat detached," serving in a sense as the translator of a world of "customs, flora and fauna" unknown to the European reader (Ibid.: 154). It was in The Lonely Londoners that Selvon worked out a technique capable of reconciling authenticity with narrative coherence. Working within the context of Caribbean immigrants in London, Selvon used language as a filter for the experience of his characters in an unfamiliar world. In his discussion of the novel, Fabre emphasizes the importance of language not as a reflector of Caribbean origin, but as a narrative device permitting the narrator to bridge the gap between Caribbean content and European form. As Fabre says:

Selvon's problem lay in reducing the distance between the European reader and the characters; he managed this by having the narrator also speak modified dialect subtly interwoven with standard English in lyrical monologues. (Ibid.: 156)

In the answers he gave to questions that Fabre asked him about his use of dialect, Selvon emphasized the way in which modifying the relation between standard and dialectical forms of English in The Lonely Londoners allowed him to solve the problem of narrative form. In answer to a question about his use of dialect in the novel, Selvon insisted:

When I wrote the novel that became The Lonely Londoners, I tried to recapture a certain quality in West Indian everyday life. I had in store a number of wonderful anecdotes and could put them into focus, but I had difficulty starting the novel in straight English. The people I wanted to describe were entertaining people indeed, but I could not really move. At that stage, I had written the narrative in English and most of the dialogues in dialect. Then I started both narrative and dialogue in dialect and the novel just shot along. (Fabre 1988, 66)

5 The way that Selvon talks about his use of dialect in the interview with Fabre clearly shows that at the time he wrote the novel, orality had not yet become an important dimension of Caribbean creativity in both artistic and ideological terms. Laurence Breiner, in his study of West Indian poetry, evokes some of the factors explaining the appearance of what is often termed "nation language" in novels written by Caribbeans living abroad before its appearance in poetry printed in the region. He mentions the fact that the use of dialect was immediately taken as a reflection of social status; he also evokes the problem of giving a written form to a language experienced orally and possessing no standard written form. Finally, he underlines the relation of dialect to literary form, stressing the fact that it is generally used as a vehicle for comedy and irony:

It is a cross-cultural commonplace that dialect first enters any literature as a device for comedy, as an admirable means for depiction in the low mimetic style. Its most 
obvious value is in the representation of character, and in the directness with which it can distinguish a voice from that of the poet. Dialect is the sound of someone the poet hears, but is not. (Breiner, 165) the aspects of dialect referred to by Breiner although he did not possess the critical distance at the time to pinpoint the relationship between his use of dialect and its wider presence in fiction and poetry. His search for an appropriate language was based to some extent on instinct, but his instincts proved to be highly appropriate and contributed in significant ways to making dialect an effective tool for the representation of Caribbean culture. Selvon was clearly aware of the problems posed by the writing of dialect; he explained in his interview with Fabre that he "modified the

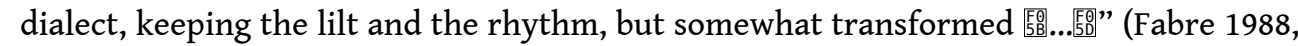
66). Asked whether he had actually "fabricated" the dialect, he pursued his reflection on the subject:

I did not pick the Jamaican way of talking in London. I only tried to produce what I believed was thought of as a Caribbean dialect. The modified version in which I write my dialect may be a manner of extending the language. It may be called artificial and fabricated. The way I treat the language is not the way it is spoken in Jamaica, or Barbados, or Trinidad either, for that matter. I only resorted to a modified Trinidadian dialect because, much more than Jamaican or Barbadian English, it is close to "correct Standard English", and I thought it would be more recognizable to the European reader. (Ibid., 67)

Using a modified dialect to "extend" the language was a judicious choice, for Selvon was not simply making the language easier to understand. He was increasing the capacity of the language to become a dimension of the narrative, to express more than just a Caribbean reality. He was ultimately creating what Bakhtin would call an "image" of the language, thus bringing it into dialogic tension with the other languages of the English novel. This was Selvon's stroke of genius and Fabre's insistence on the crucial role played by language in determining the structure and technique of Selvon's fiction contributed to bringing the author's acuity in this area to light.

The use of dialect is, of course, only one aspect of orality. To emphasize orality is not only to represent the way people speak, but to allow the story itself to be shaped by the forces that are active in a society in which orality plays an important role. Selvon was not consciously attempting to represent a culture based on orality in the way that Earl Lovelace and Robert Antoni would do so later on, but he nonetheless discovered that the anecdotic nature of storytelling among the Caribbeans represented in The Lonely Londoners reflected an important aspect of the life of Caribbeans, they way they relate to each other and to experience ${ }^{4}$. He said in speaking of the novel:

When I wrote the novel that became The Lonely Londoners, I tried to recapture a certain quality in West Indian everyday life. I had in store a number of wonderful anecdotes, both about Trinidad and immigrants in London. I had wonderful anecdotes and could put them into focus, but I had difficulty starting the novel in straight English. (Ibid., 66)

By putting what he called a "modified dialect" in the mouth of the novel's homodiegetic narrator, Selvon found a way of bringing the story closer to the language in which it was expressed, as if the story itself were above all the story of a language forged in the experience of a multicultural city. Thus Selvon was not simply using dialect; he was writing a novel strongly influenced by the notion of orality. The way in which the characters and the narrator express themselves and communicate with each 
other and with the reader does not only reflect dialectal forms of speech. The novel itself, its story and themes, are based to a large extent on the principles of a culture in which orality plays an important role.

Since the publication of Selvon's London novel, the use of orality has become an increasingly important means of adapting narrative technique to the specific nature of Caribbean themes. Accompanying explorations of the use of orality in poetry, theater and fiction is a growing body of theoretical writing which has been used to elucidate and clarify the practice of written representations of orality. Bakhtin's work on the polyphonic nature of the novel has been particularly useful as an approach to the relation between form and content, as has Walter Ong's study of the relation between writing and orality ${ }^{5}$. The use of orality by Caribbean writers has been accompanied in many cases by a theoretical and ideological reflection on the subject, particularly on the part of writers who see the use of orality as a tool for freeing the representation of Caribbean experience from the stranglehold of European aesthetics. This is true in particular of writers from the French-speaking Caribbean like Edouard Glissant, Patrick Chamoiseau and Raphaël Confiant, for whom orality offers an alternative grid for reading history and for interpreting the forms of cultural expression. In their collective work In Praise of Creoleness, Chamoiseau, Confiant and Bernabé express their confidence in the possibility of recovering the essence of past forms without sacrificing their modernity: "In short, we shall create a literature, which will obey all the demands of modern writing while taking roots in the traditional configurations of our orality" (Bernabé, Chamoiseau, Confiant, 98).

11 At the end of the chapter on Sam Selvon in the collection of essays edited by Bruce King, Michel Fabre sums up Selvon's contributions to Caribbean fiction, emphasizing in particular the way in which Selvon "achieved a convergence of the written and oral modes in Trinidad, largely by bridging the gap between local Creole and accepted standard English" (Fabre 1995, 162). He also points out that Selvon's books, like those of a number of Caribbean authors, went out of print before being rediscovered by a new generation. The Lonely Londoners is currently available in a Penguin Modern Classics edition with an introduction by Susheila Nasta. The Lonely Londoners, although published at a time when the use of orality had not yet become an important tool in the postcolonial struggle to define a Caribbean aesthetic, still constitutes one of the most successful uses or orality in fiction written by a Caribbean author. The very modesty and apparent simplicity of the novel are deceptive, for while writers like Chamoiseau, and to some extent Robert Antoni, oblige the reader to make a considerable effort to enter the universe which they construct through an invented Creole, Selvon draws the reader almost effortlessly into his world. The underpinnings of this apparent simplicity merit investigation, for they provide important clues to the successful use of orality. They also offer an interesting opportunity to explore the relation between orality and the notion of voice, two ideas which although related are not identical. Orality, while suggesting the idea of performance and the presence of sound, can be represented by language. But voice, as Mladen Dolar has recently demonstrated, cannot be reduced to language and reveals an irreducible tension between sound and meaning.

One of the major difficulties facing novelists like Selvon, who wish to create effects of orality, is to reconcile the nature of a folk culture, rooted in orality, with the conventions of the novel, which, as Walter Ong clearly demonstrates, make sense only in terms of a culture based on writing. For Ong, the most important characteristic of an 
oral culture is what he calls its "context dependency" (Ong, 105). It is writing that introduces a distance between context and cultural expression, making possible a complex representation of fictional worlds which are self-explanatory. The intimate link between orality and the contexts in which it is produced and performed makes it difficult for a writer to use orality in a work aimed partly at an audience unfamiliar with the context of its production and performance. This was clearly part of the dilemma facing Selvon, who explained to Michel Fabre that his West Indian characters "live from day to day, with ups and downs; encounters and chance occurrences are just as important as social rituals" (Fabre 1988, 66). Placing his characters in the context of London, where they would find themselves obliged to live "from day to day", outside of the social rituals that define English life, proved to be an appropriate way of transforming the episodic quality of the characters' lives into a credible narrative; the story of their adaptation to London becomes the narrative of their search for a language capable of making their experience understandable to themselves and to each other. This was Selvon's way of "extending the language" by showing that all experience can be seen as a quest for a language in which to interpret the world to oneself and to others. Seen in this perspective, the seemingly episodic quality of the novel reveals an underlying structure in which language plays a major role. In this respect, the relation between Moses, the character who initiates the other West Indians into the secrets of life in London is particularly important, for Moses, while sharing the dialect of his fellow West Indians, must teach them to speak the language of the city. However, the language used by Moses is also filtered through that of the homodiegetic narrator, who, while not figuring as an explicitly named character in the novel, shares their language and their view of the world. It is through his use of this type of narrator that Selvon was able to give dramatic and tonal unity to his narrative. It is the narrator who sets the tone and rhythm of the narrative, gradually drawing the reader into his way of presenting the world, seducing him with the use of a dialect that goes almost unnoticed, that presents no obstacle to the reader's understanding, but that determines his perception of the story being told. It is at this level that the dialect "modified" by Selvon plays a crucial role, for the reader listens directly to the narrator, who is the final interpreter, the one who initiates him into the world of the West Indians in London, through a process parallel to that being carried out by Moses in relation to the other characters.

13 It is possible to analyze the language used by the narrator in terms of vocabulary and syntax. It is clear that the choice Selvon makes of terms coming from Trinidadian English, like "coast a lime" or from standard English serves to trace the frontier between the narrator's West Indian perspective and his appropriation of a new context. When the narrator describes a newcomer by saying, "Bart have light skin. That is to say, he neither here nor there, though he more here than there," he is emphasizing his understanding of a standard English expression while using it to situate, ironically, the man whose assimilation will be seen in terms of color. (Selvon $1956: 46)$ Thus, the question of color and difference, a standard preoccupation in fiction about West Indians in Europe, is given a linguistic equivalent.

Although Michel Fabre did not link Selvon's use of language directly to the idea of orality and the creation of effects of orality in fiction, an area of critical investigation which has developed fairly recently, he clearly perceived the importance of the relation between language and Selvon's search for a form and structure appropriate to his desire to represent language as a metaphor for a folk culture. Since the publication of 
his interviews and articles on Sam Selvon, the author has been the subject of several books and a number of articles. The focus of academic criticism obviously reflects the shifting of the critical frames used to examine authors from the region. The Bakhtinian models of carnival and dialogism have come to be seen as appropriate paradigms for talking about Selvon's use of folk culture and dialect. Most critics agree that the key to his success in finding a narrative structure adapted to the experience of his West Indian "boys" in London lies in his use of language ${ }^{6}$. As is often the case, critics vying for credibility tend to adopt conflicting positions. Curdella Forbes, in From Nation to Diaspora: Sam Selvon, George Lamming and the Cultural Performance of Gender, sees the ritualistic aspect of the boys' verbal performance as the mark of "moorings lost" and "unproductive litanies", the sign of their rejection of women as the bearers of order and social responsibility (Forbes, 80, 88). Mark Looker essentially uses the notion of space, an increasingly common parameter in literary criticism, to examine The Lonely Londoners as a Caribbean reinvention of the urban fiction of Dickens and Zola. For Looker, the novel's structure is based on "the narratability of the city, which includes inventing a language, sifting new words and phrases out of the imperial lexicon and wielding that language to name and create" (Looker, 60).

The emergence of new frames in which to examine literary texts does not discredit former approaches, for the groundwork in areas like the study of Caribbean fiction requires a willingness to explore little-known authors and to attempt to read them on their own terms while at the same time drawing them into theoretical frames which make their narrative strategies more visible. Michel Fabre brought to his extensive exploration of Selvon an awareness of the way in which African-American authors had tried to mobilize the resources of their own culture and language in order to invent creative strategies of their own. While other critics evoke Selvon's relation to English authors like Dickens, Eliot and Conrad, he immediately detected a connection with Claude McKay, Langston Hughes, Ralph Ellison and Ishmael Reed.

The notion of voice is one of the concepts that has emerged recently as a subject of academic interest, partly because of the numerous ways in which the term is used and its relative ambiguity as a concept. Derrida's exploration of the phonocentric bias of Western philosophy, combined with Genette's mathematical precision in locating voice as a dimension of narrativity, have, if anything, made the paradoxes of voice appear even more complex. Works like Mladen Dolar's fascinating study A Voice and Nothing More can offer approaches to the complex philosophical, linguistic and psychoanalytic implications of voice that make it possible to explore the way a writer working with effects of orality attempts to deal with the tension between written and oral expression in a way that draws attention to the ambiguous status of voice, caught between the flesh and the soul, between sound and meaning.

Dolar attempts to show, in a variety of different ways, that the notion of voice relies on the tension between sound and meaning, and that there is no way of eliminating this tension without losing the very idea of voice. He demonstrates that the differential system on which modern linguistics, and thus phonology, is based cannot take into account the voice, which he compares in its functioning with the Matrix from the movie:

In order to speak one has to produce the sounds of a language in such a way as to satisfy its differential matrix, which behaves quite a bit like the Matrix in the movie. The signifier needs the matrix as its support, just as the Matrix needs the poor subjects and their fantasies, but it has no materiality in itself, it just uses the 
voice to constitute our common "virtual reality." But the problem is that this operation always produces a remainder which cannot be made a signifier or disappear in meaning; the remainder that doesn't make sense, a left-over, a cast-off -shall we say an excrement of the signifier? The matrix silences the voice, but not quite. (Dolar, 20)

18 A writer like Selvon, who attempts to reproduce the effects of orality in everyday life, is, essentially, working with this paradoxical tension between sound and meaning, trying to make use of it in esthetic terms. The reader "hears" the dialect spoken by Selvon's characters because it clashes in significant ways with the system of standard English, thus producing a noise, a remainder, to use Dolar's term, which draws attention to language itself and to the ways in which it produces meaning. It is the gap, the discrepancy between standard English and dialect, that the reader hears and that leads him to search for the significance of this difference, to account for it in terms of meaning. In order to make the use of dialect effective in narrative terms, a writer must extend its effects to the narrative itself, thus capitalizing on the reader's ability to decode an unknown language at several levels. Selvon does this by creating a discrepancy between dialogue and story that reflects the ephemeral and unstable nature of lives that are lived in the moment, through verbal exchange. This explains why the language of Selvon's London immigrants fluctuates in a perpetual gap between sound and meaning and is marked by mimicry, redundancy, misperception and approximation. It also accounts for the episodic, anecdotal nature of the novel as a whole. Not only do the characters need to invent a language in which to talk about London, to deal with the city. They need to invent a narrative appropriate to the language. However the quest for meaning performed in these verbal exchanges is not suppressed; it is simply deferred, leaving a space in which language can reveal its elusive relation to its hidden other, the "vanishing mediator" evoked by Dolar that "goes up in smoke in the meaning being produced" (Ibid., 15). The enigmatic homodiegetic narrator, who orchestrates the other voices, is not to be seen as an ultimate "voice" in the traditional sense of the term, as the origin of the novel's meaning and the guarantee of its final coherence. He enters into dialogic conversation with all the other voices. He is, in a sense, the voice within the other voices, the marker of the tension between language and utterance that constitutes Dolar's definition of voice. He suggests the poetic potential of the language of the London boys without freezing it into a stabilized meaning. His long stream-of-consciousness monologue, rhapsodizing on the pleasures of summer in London, with its echoes of Virginia Woolf and James Joyce, does not so much take the novel to a higher, more literary plane, as deepen the mystery of voice, making it impossible to determine where it is coming from or how it creates its seductive charm. The voice of the homodiegetic narrator, which has been the center of much of the discussion of The Lonely Londoners, shares with all such stream-of-consciousness voices an essentially acousmatic ${ }^{7}$ nature, making it appear to come both from inside and outside the reader, transforming it into something which is both intimate and exotic. Selvon achieved this effect, not simply by mimicking other stream of consciousness narratives, but by working from inside his own sense of language and its relation to sound and voice, gradually bringing the rhythms of his invented Caribbean dialect into harmony with the voices he heard in the English of Eliot, Woolf and Joyce. Yet he remained constantly aware of the fact that what he was creating was pure artifice, the verbal equivalent of what it means to be a Caribbean in London. He reminds the reader of this when he has Daisy, Galahad's English girlfriend, ask him to repeat the question he has just asked in perfectly 
"readable" English. When Galahad asks her, 'You get that raise the foreman was promising you?', Daisy answers, 'What did you say? You know it will take me some time to understand what you say. The way you West Indians speak!' (Selvon 1956, 82).

Robert Antoni, a contemporary novelist from Trinidad, has had considerable success with a technique very like Selvon's, although developed and extended in more complex and elaborate ways. His ambitious novel, Divina Trace, situated in an island that is supposed to resemble Trinidad, explores the ways in which an oral culture develops and circulates narratives. Antoni, like Selvon, is fascinated by the sound of voices and the way in which an invented dialect can allow the reader to hear the voices that produce stories. In talking about his use of an invented creole in a lecture given in Antwerp, he referred explicitly to his debt to Selvon. ${ }^{8}$ The re-editing of Selvon's fiction, along with that of other Caribbean novelists from the crucial period of the fifties and sixties, shows that the value and appeal of his fiction is far more universal than was thought at one time, although it should be remembered that even as important a novelist as William Faulkner was allowed to go out of print before Malcolm Cowley published The Portable Faulkner.

Michel Fabre contributed to bringing Caribbean authors to the attention of academic circles in Europe and the United States and enlarged the perspectives available for reading these authors by examining their narrative strategies with those mobilized by a growing number of African American writers. The thoroughness of his investigation of Selvon's fiction serves as a reminder that our critical approach to fiction needs to be rooted in a broad base and nourished by a constant interaction between the known and the unfamiliar. While Selvon's fiction is still not familiar to most readers, the interest in orality and voice in contemporary criticism offers an occasion to revisit Selvon's novels through critical and theoretical frames which, while not superceding those that already exist, could potentially enhance the universality of his appeal and deepen our understanding of the very nature of orality and its use in fiction.

\section{BIBLIOGRAPHIE}

ANTONI, Robert, Divina Trace, New York, The Overlook Press, 1992.

BERNABÉ, Jean ; CHAMOISEAU, Patrick ; CONFIANT, Raphaël, Eloge de la créolité: In Praise of Creoleness, texte traduit par M.B. Taleb-Khyar, Paris, Gallimard, 1993; Baltimore, Johns Hopkins University Press, 1990.

BREINER, Laurence A., An Introduction to West Indian Poetry, Cambridge, Cambridge University Press, 1998.

DOLAR, Mladen, A Voice and Nothing More, Cambridge, MIT Press, 2006.

DURIX, Jean-Pierre, "Pour notre 'grand-frère' Michel Fabre," in Places of Memory: Essays in Honour of Michel Fabre, special edition of Commonwealth: Essays and Studies, SP5, 2003, 5-7. 
FABRE, Michel, "Samuel Selvon: Interviews and Conversations," in Susheila NASTA, ed., Critical Perspectives on Sam Selvon, Washington, Three Continents Press, 1988, pp. 64-76.

"From Trinidad to London: Tone and Language in Samuel Selvon's Novels," in Susheila NASTA, op. cit., 213-222.

-------, “Samuel Selvon,” in Bruce KING, ed., West Indian Literature, $2^{\text {nd }}$ ed., London, Macmillan, 1995, 152-162.

"Moses and the Queen's English: Dilaect and Narrative Voice in Samuel Selvon's London Novels," World Literature Written in English 21.2, Summer 1982, 385-392.

-------, “The Queen's Calypso: Linguistic and Narrative Strategies in the Fiction of Sam Selvon," Commonwealth: Essays and Studies 3, 1977-1978, 69-76.

FORBES, Curdella, From Nation to Diaspora: Sam Selvon, George Lamming and the Cultural Performance of Gender, Mona, University of West Indies Press, 2005.

HOLQUIST, Michael, ed., texte traduit par Caryl Emerson et Michael Holquist, The Dialogic Imagination: Four Essays by M. M. Bakhtin, Austin, University of Texas Press, 1981.

LOOKER, Mark, Atlantic Passages: History, Community and Language in the Fiction of Sam Selvon, New York, Peter Lang, 1996.

ONG, Walter, Orality and Literacy 區1982嚂, London, Routledge, 1988.

ROHLEHR, Gordon, “The Folk in Caribbean Literature," Reprinted in Susheila NASTA, op. cit., 29-43.

SELVON, Sam, A Brighter Sun 沼1952區, London, Longman, 1985.

------, The Lonely Londoners 惃1956医, London, Penguin, 2006.

------, Moses Ascending 臨1975硻, London, Penguin, 2008.

\section{NOTES}

1. Jean-Pierre Durix, "Pour notre 'grand-frère' Michel Fabre," in Places of Memory: Essays in Honour of Michel Fabre, special edition of Commonwealth: Essays and Studies, SP5 (2003), 5.

2. Samuel Selvon's novels include A Brighter Sun (1952), An Island is a World (1955), The Lonely Londoners (1956), Turn Again Tiger (1958), and Moses Ascending (1975). This article will essentially be devoted to a discussion of The Lonely Londoners.

3. "Samuel Selvon: Interviews and Conversations" in Susheila Nasta, ed., Critical Perspectives on Sam Selvon (Washington: Three Continents Press, 1988), 64-76; "From Trinidad to London: Tone and Language in Samuel Selvon's Novels" in Susheila Nasta, op. cit., 213-222; "Samuel Selvon" in Bruce King, ed., West Indian Literature, $2^{\text {nd }}$ edition (London: Macmillan, 1995), 152-162; "Moses and the Queen's English: Dialect and Narrative Voice in Samuel Selvon's London Novels," World Literature Written in English, 21.2 (Summer 1982) 385-392; “The Queen's Calypso: Linguistic and Narrative Strategies in the Fiction of Sam Selvon," Commonwealth: Essays and Studies, 3 (1977-1978), 69-76.

4. Earl Lovelace, novelist from Trinidad, author of a number of well-known novels, in particular The Wine of Astonishment, The Dragon Can't Dance and Salt. Robert Antoni, a contemporary novelist whose family originally came from Trinidad, is the author of Divina Trace, an ambitious novel relying heavily on the use of orality, Blessed is the Fruit and Carnival. 
5. Michael Holquist, ed., The Dialogic Imagination: Four Essays by M.M. Bakhtin; Walter Ong, Orality and Literacy.

6. This dimension had already been pointed out by F. Gordon Rohlehr in his article "The Folk in Caribbean Literarature, reprinted in Susheila Nasta's Critical Perspectives: “The 'boys', who have originated from a world of language, recreate in the big city a world of words in which they move, and through which they grope for clarity in the midst of experience as bewildering and vague as the London fog" (Nasta, 41). Mark Looker in Atlantic Passages: History, Community, and Language in the Fiction of Sam Selvon makes explicit use of the Bakhtinan model to express the same idea.

7. According to Dolar's definition, an acousmatic voice "is simply a voice whose source one cannot see, a voice whose origin cannot be identified, a voice one cannot place" (Dolar, 60).

8. These remarks were made in the course of a lecture given during the International Conference "Injustice and Insubordination: The Caribbean Writer as "Warrior of the Imaginary" organized by the Society of Caribbean Research and the Postcolonial Literatures Research Group at the University of Antwerp in September, 2003.

\section{AUTEUR}

\section{KATHIE BIRAT}

Université de Metz 